\title{
Hybrid composites reinforced with short sisal fibres and micro ceramic particles
}

\author{
Francisco Margotti dos Santos ${ }^{1}$, Fabiano Bianchini Batista ${ }^{1}$, \\ Tulio Hallak Panzera ${ }^{1}$, André Luis Christoforo ${ }^{2}$, \\ Juan Carlos Campos Rubio ${ }^{3}$
}

\author{
${ }^{1}$ Centre for Innovation and Technology in Composite Materials - CIT ${ }^{\mathrm{e}}$, UFSJ, São João Del-Rei, MG \\ e-mail: franciscomargotti@gmail.com; fabianchini@ufsj.edu.br; panzera@ufsj.edu.br \\ ${ }^{2}$ Centre for Innovation and Technology in Composite Materials - CIT ${ }^{\mathrm{C}}$, UFSCar, São Carlos, SP \\ e-mail: alchristoforo@ufscar.br \\ ${ }^{3}$ Departament of Production Engineering, UFMG, Belo Horizonte, MG \\ e-mail: juan@demec.ufmg.br
}

\begin{abstract}
Biocomposites reinforced with natural fibres have been extensively investigated as a promising replacing material for synthetic ones, such as the glass fibre reinforced composites. The length of natural fibres depends not only on the plant species, but also on the extraction processing. The heterogeneity of natural fibres, in terms of length, can be considered a problem for some industrial applications. A little amount of work has been conducted towards the use of short natural fibres in composite materials. In order to balance the reduction of strength due to the use of short length fibres, ceramic particles can be incorporated. This paper describes the experimental characterization of hybrid biocomposites consisted of epoxy polymer, short random sisal fibres and Portland cement particles. A full factorial design was performed to investigate the effect of the factors and levels, such as fibre length $(4 \mathrm{~mm}$ and $8 \mathrm{~mm})$ and Portland cement inclusion $(0 \mathrm{wt} \%$, $5 \mathrm{wt} \%$ and $10 \mathrm{wt} \%$ ) on the following properties, flexural modulus and strength (via three-point bending test), damping ratio, apparent porosity and water absorption. The fibre volume fraction was kept constant at $25 \%$. The Design of Experiment (DoE) analysis revealed the "Fibre length" factor does not affect the responses. The interaction "Fibre length and Cement inclusion" affected only the stiffness. Portland cement particles statistically revealed a noticeable contribution to the apparent porosity and water absorption. The presence of cement particles at $5 \mathrm{wt} \%$ provided not only the increase in the damping ratio response, but also the reduction in the flexural strength and stiffness.
\end{abstract}

Keywords: Hybrid composites, biocomposites, sisal fibres, Portland cement.

\section{INTRODUCTION}

Polymeric composite materials reinforced with natural fibres have been widely investigated to obtain new materials with sustainable characteristics [1-6]. Natural fibres have low cost when compared to glass and carbon fibres, besides lead to important renewable characteristics [1]. Sisal fibres present hallmark characteristics such as lightweight, non-toxic, high specific modulus and strength, a cost ten times less than the glass fibre, besides being less abrasive to equipment and moulds [2]. ANGRIZANI, et al. [2] have emphasized the aggregated value of sisal fibres is amplified when used as reinforcement in polymeric composites. These factors make sisal the most studied natural fibres worldwide. However, the discontinuous fibre length and diameter make them infeasible for industrial applications. MARTIN, et al. [3] have reported a fibre diameter variation greater than $65 \%$ from the basal $(0-30 \mathrm{~cm})$ to apexes $(90-120 \mathrm{~cm})$ parts of the sisal sheet plant. The toughest part of sisal fibre is located about $30 \mathrm{~cm}$ to $60 \mathrm{~cm}$ from its base and the lowest performance is found for the apical region. In this context, a possible alternative for the use of sisal fibres in industrial applications can be related to the use of short sisal fibres.

It is well known that composites reinforced with short fibres are not as strong or as stiff as continuous fibres [4]. However, these composites have attractive features that make them interesting for certain applications, i.e., in components with complex geometry and shape, in which continuous fibres are not suitable for the fabrication without damages [4]. Composite materials of short random fibres can be considered isotropic structures, while the continuous ones are highly anisotropic. PAUL, et al. [5] have 
studied low-density polyethylene composites reinforced with short sisal fibres $(6 \mathrm{~mm})$ testing a set of treatments on the electrical properties of the composites. A variety of surface treatments such as alkali, stearic acid, peroxide, permanganate and acetylation have been evaluated to improve the interfacial bonding of sisal fibres. PAIVA, et al. [6] have analysed the thermal stability of unmodified and modified short sisal fibres $(3 \mathrm{~mm})$ of phenolic and lignophenolic based composites.

Significant improvements on the mechanical performance of polymeric composites have been reported when ceramic particle inclusions were combined with the matrix phase [7-12]. CAO and CAMERON [7] have investigated the effect of silica particle inclusions on the impact resistance of glass fibre composites made with epoxy resin. Stiff particles are able to increase the mechanical strength of the composites minimizing the onset and rate of crack propagation. This effect depends not only on the amount, but also on the sizes and densities of the particles, i.e. microparticles has been investigated up to $33 \mathrm{wt} \%$ [79], while nano-sized particles has been considered up to $5 \mathrm{wt} \%$ [12-13].

When a crack propagation reaches a ceramic particle along the fibre-matrix interface, the crack front cannot break it, as a consequence, additional effort is required to spread across the interface fibre/particle or the interface between particle/matrix. As a result, a lower rate of crack propagation has been observed, increasing the strength of the composites [1, 7]. SILVA, et al. [8] have investigated the effect of silica micro particles and maleic anhydride inclusions into polymeric matrix (epoxy resin) of composites with unidirectional sisal fibres. The factors investigated were the fibre volume fraction $(30 \%$ and $50 \%)$, the mass fraction of silica micro particles $(0 \mathrm{wt} \%, 20 \mathrm{wt} \%$ and $33 \mathrm{wt} \%)$ and the mass fraction of maleic anhydride $(0 \mathrm{wt} \%$ to $2 \mathrm{wt} \%)$. The results have revealed the micro silica inclusions did not significantly affect the flexural strength, while the interaction between "fraction of fibres, silica particles and maleic anhydride" has played a major role not only on the flexural strength, but also on the flexural modulus [8].

This work investigates the effect of Portland cement inclusions and sisal fibre lengths on the physical, dynamic and mechanical behaviour of short sisal fibre reinforced composites. A full factorial design was conducted to identify the effects of individual factors or interactions on the responses.

\section{MATERIALS AND METHODS}

The composite specimens were fabricated manually. The epoxy resin and hardener were CMR 028 and HY951, respectively. A resin/hardener ratio of 10:1 was considered. The sisal fibres were supplied by Sisalsul Company (São Paulo - Brazil). The matrix phase was modified by the incorporation of Portland cement particles (Holcim Company, ASTM III type). Firstly, the resin and the hardener were combined, then the Portland cement particles were added and hand-mixed for 5 minutes at room temperature $\left(\approx 23^{\circ} \mathrm{C}\right)$. A wood mould covered by Armalon (a demoulding tissue) was used to laminate the composites. The sisal fibres were cut in lengths of $4 \mathrm{~mm}$ and $8 \mathrm{~mm}$ and spread out manually in the mould. Subsequently, the epoxy matrix (modified and non-modified) was spread upon the fibres and cold-pressed at 2.5 tonnes for 12 hours.

The experimental factors such as sisal fibre length $(4 \mathrm{~mm}$ and $8 \mathrm{~mm})$ and weight fraction of cement particles $(0 \mathrm{wt} \%, 5 \mathrm{wt} \%$ and $10 \mathrm{wt} \%)$ were investigated, providing a full factorial design of $2^{1} 3^{1}$, resulting in 6 experimental conditions (see Table 1). The fibre volume fraction was kept constant at $25 \%$ based on preliminary analysis results. Twenty grams $(20 \mathrm{~g})$ of short sisal fibres were used to fabricate each lamina; this is the equivalent mass of five layers of unidirectional sisal fibre laminate.

Table 1: Experimental conditions, full factorial design $\left(2^{1} 3^{1}\right)$.

\begin{tabular}{c|c|c}
\hline CONDITIONS & FIBRE LENGTH (mm) & CEMENT INCLUSION (wt\%) \\
\hline $\mathrm{C} 1$ & 4 & 0 \\
\hline $\mathrm{C} 2$ & 4 & 5 \\
\hline $\mathrm{C} 3$ & 4 & 10 \\
\hline $\mathrm{C} 4$ & 8 & 0 \\
\hline $\mathrm{C} 5$ & 8 & 5 \\
\hline $\mathrm{C} 6$ & 8 & 10 \\
\hline
\end{tabular}

After 14 days of curing at room temperature $\left(\approx 23^{\circ} \mathrm{C}\right)$, the composite plates (Figure 1a) were cut based on the recommendations of ASTM D790 [14] obtaining prismatic specimens (see Figure 1b) for the threepoint bending test. Ten specimens were fabricated for each experimental condition. Two replicates and 6 
experimental conditions were performed running a total of 120 specimens. The replicate consists on the repetition of the experimental conditions, which offers the estimative of the experimental error of the individual response. The extension of this error is important to decide the existence or not of significant effects attributed to factor action [15]. The responses investigated in the experiment were: flexural modulus and strength [14], damping ratio, apparent porosity and water absorption [17]. A Shimadzu AG-X Plus testing machine of $100 \mathrm{KN}$ capacity was used to perform the flexural tests (via three-point bending tests with a span to depth ratio of 16). The testing speed was set at $2 \mathrm{~mm} / \mathrm{min}$ [14].
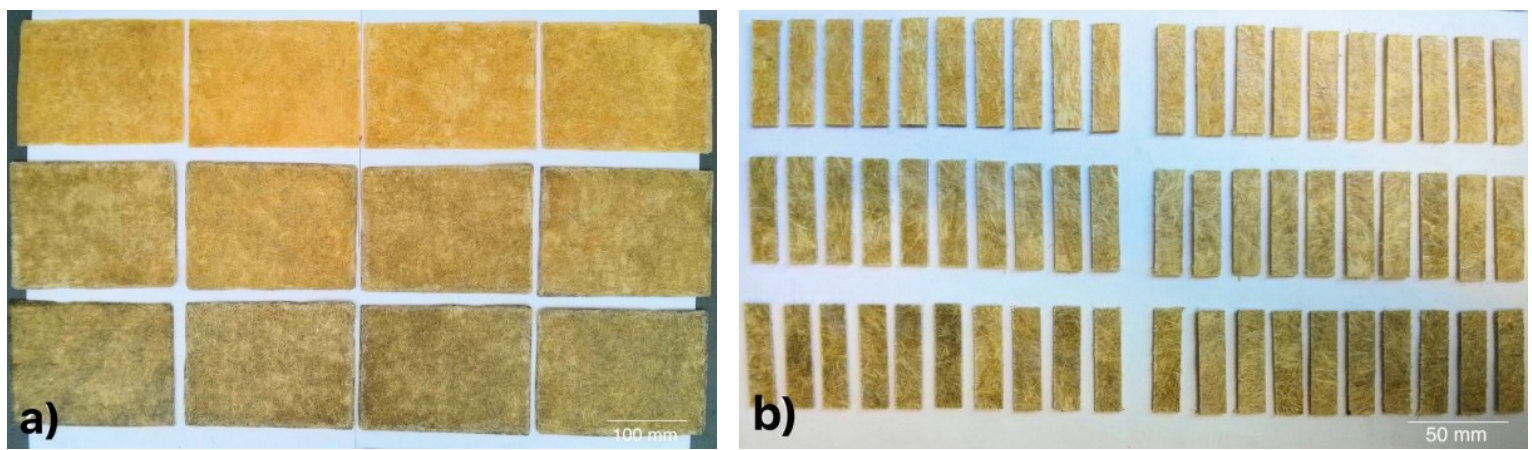

Figure 1: Composite laminas (a) and flexural specimens (b).

The damping represents the capability of the system to dissipate energy; the damping ratio $(\zeta)$ is a dimensionless number that provides an amount of damping that acts on the real system [16]. A high damping ratio value $(\zeta)$ is indicative of a material having high, non-elastic strain component while a low value indicates high elasticity. The increase in the fibre/matrix interface bonding has led to the reduction in damping ratio, since the mobility of the molecular chains at the fibre/matrix interface decreases [17]. The equipment used to perform the damping tests was a Polytec OFV-503 Sensor Head.

The apparent porosity and water absorption analysis were carried out according to recommendations of British Standard BS EN ISO 10545-3 [18]. Apparent porosity is a measure of the void spaces in a material, and it is measured as a fraction, between 0 and 1, or as a percentage; and water absorption of a material is the percentage of water absorbed after immersion in water under constant negative pressure. The statistical software Minitab 17 was used to manipulate the data using the Design of Experiment (DoE) and Analysis of Variance (ANOVA) tools.

\section{RESULTS}

Table 2 shows the mean results of the properties for each experimental condition. Table 3 shows the ANOVA results for the responses. If the P-values are less than or equal to 0.05 , it is concluded that the relevant effect is significant. A $\alpha$-level of 0.05 is the level of significance that implies a $95 \%$ of reliability of the effect being significant [19]. The underlined P-values shown in Table 3 indicate the significant factors identified in this study. The adjusted $\mathrm{R}^{2}$ value indicates whether the model behaved appropriately. This means that the variance of the properties is explained by the variance of experimental factors such as the fibre length and Portland cement inclusion factors. When one or more interaction effects are significant, the factors that interact can be considered together [20]. $\mathrm{R}^{2}$ values close to 1 (or $100 \%$ ) indicate a very significant predictive ability of the model $[19,20]$. The $\mathrm{R}^{2}$ values given in Table 3 varied between $68.68 \%$ and $83.52 \%$. A normality test via Anderson-Darling technique was used to validate the ANOVA. In this case, P-values must be equal or superior to 0.05 to follow a normal distribution configuration. All data followed a normal distribution showing P-values higher than 0.05 as shown in Table 3.

Table 2: Mean of the experimental results for the responses.

\begin{tabular}{l|l|l|l|l|l}
\hline CONDITIONS & $\begin{array}{l}\text { FLEXURAL } \\
\text { STRENGTH (MPa) }\end{array}$ & $\begin{array}{l}\text { FLEXURAL } \\
\text { MODULUS (GPa) }\end{array}$ & $\begin{array}{l}\text { DAMPING RA- } \\
\text { TIO }\end{array}$ & $\begin{array}{l}\text { APPARENT PO- } \\
\text { ROSITY (\%) }\end{array}$ & $\begin{array}{l}\text { WATER AB- } \\
\text { SORPTION (\%) }\end{array}$ \\
\hline $\mathrm{C} 1$ & 36.49 & 1.55 & 0.0274 & 15.12 & 14.00 \\
\hline $\mathrm{C} 2$ & 29.38 & 1.27 & 0.0336 & 20.92 & 20.83 \\
\hline $\mathrm{C} 3$ & 36.84 & 1.75 & 0.0286 & 17.14 & 15.73 \\
\hline
\end{tabular}




\begin{tabular}{l|l|l|l|l|l}
\hline $\mathrm{C} 4$ & 35.30 & 1.49 & 0.0267 & 15.61 & 14.64 \\
\hline $\mathrm{C} 5$ & 34.15 & 1.38 & 0.0337 & 21.26 & 21.35 \\
\hline C6 & 34.47 & 1.26 & 0.0315 & 22.95 & 22.77 \\
\hline
\end{tabular}

\subsection{Flexural modulus and strength}

The flexural modulus of the composites ranged from $1.26 \mathrm{GPa}$ to $1.75 \mathrm{GPa}$ (see Table 2). The interaction between the factors "Fibre length and Cement inclusion" exhibited significant effect, with a P-value of 0.019 (Table 3). Figure 2 a shows the interaction effect plot for the mean flexural modulus. The cement inclusions provided superior stiffness $(13 \%)$ to the pristine condition, only when $10 \mathrm{wt} \%$ of particles were incorporated in composites made with $4 \mathrm{~mm}$ fibre length. The level of $5 \mathrm{wt} \%$ of cement was not able to increase the elastic moduli of the composites. A possible hydration of the cement grains by the epoxy resin can possibly contribute to increase the stiffness of polymeric composites [21].

Table 3: Analysis of variance (P-value $\leq 0.05)$.

\begin{tabular}{|c|c|c|c|c|c|c|}
\hline EFECTS & $\begin{array}{l}\text { EXPERIMENTAL } \\
\text { FACTORS }\end{array}$ & $\begin{array}{l}\text { FLEXURAL } \\
\text { STRENGTH }\end{array}$ & $\begin{array}{l}\text { FLEXURAL } \\
\text { MODULUS }\end{array}$ & $\begin{array}{l}\text { DAMPING } \\
\text { RATIO } \\
\text { P-values } \leq 0\end{array}$ & $\begin{array}{l}\text { APPARENT } \\
\text { POROSITY }\end{array}$ & $\begin{array}{l}\text { WATER AB- } \\
\text { SORPTION }\end{array}$ \\
\hline$\frac{z}{\Sigma}$ & $\begin{array}{l}\text { FIBRE LENGTH } \\
\text { CEMENT INCLUSION }\end{array}$ & $\begin{array}{l}0.746 \\
\underline{0.050} \\
\end{array}$ & $\begin{array}{l}0.059 \\
0.071\end{array}$ & $\begin{array}{l}0.611 \\
\underline{0.037} \\
\end{array}$ & $\begin{array}{l}0.192 \\
\underline{0.044}\end{array}$ & $\begin{array}{l}0.168 \\
\underline{0.046}\end{array}$ \\
\hline 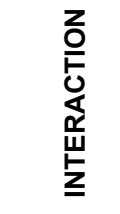 & $\begin{array}{l}\text { FIBRE LENGTH AND } \\
\text { CEMENT INCLUSION }\end{array}$ & 0.102 & $\underline{0.019}$ & 0.649 & 0.313 & 0.291 \\
\hline & $\mathrm{R}^{2}$-ADJUSTED (\%) & 73.88 & 83.52 & 68.68 & 72.65 & 73.10 \\
\hline & $\begin{array}{c}\text { Anderson-Darling } \\
\text { (P-values } \geq 0.05)\end{array}$ & 0.897 & 0.761 & 0.494 & 0.898 & 0.816 \\
\hline
\end{tabular}

The flexural strength of the composites varied between 29.38 MPa and 36.84 MPa (Table 2). The Pvalue of 0.050 underlined in Table 3 indicates that the main factor of Cement inclusion showed significance on the flexural strength results. Figure $2 b$ shows the main effect plot for the mean flexural strength data. The cement particle inclusions did not enhance the flexural strength of the composites. A percent decrease of $13 \%$ was revealed when $5 \mathrm{wt} \%$ of cement was considered. DETOMI, et al. [22] have reported the effect of ceramic particles in fibre-reinforced composites is more evident at the top beam side where compression stresses act. The cement particles incorporated below the beam neutral line have not contributed to strengthen the composites. In this sense, the composites containing $10 \mathrm{wt} \%$ of cement particles can be considered promising, since a positive effect on the durability of the matrix phase might be achieved. 

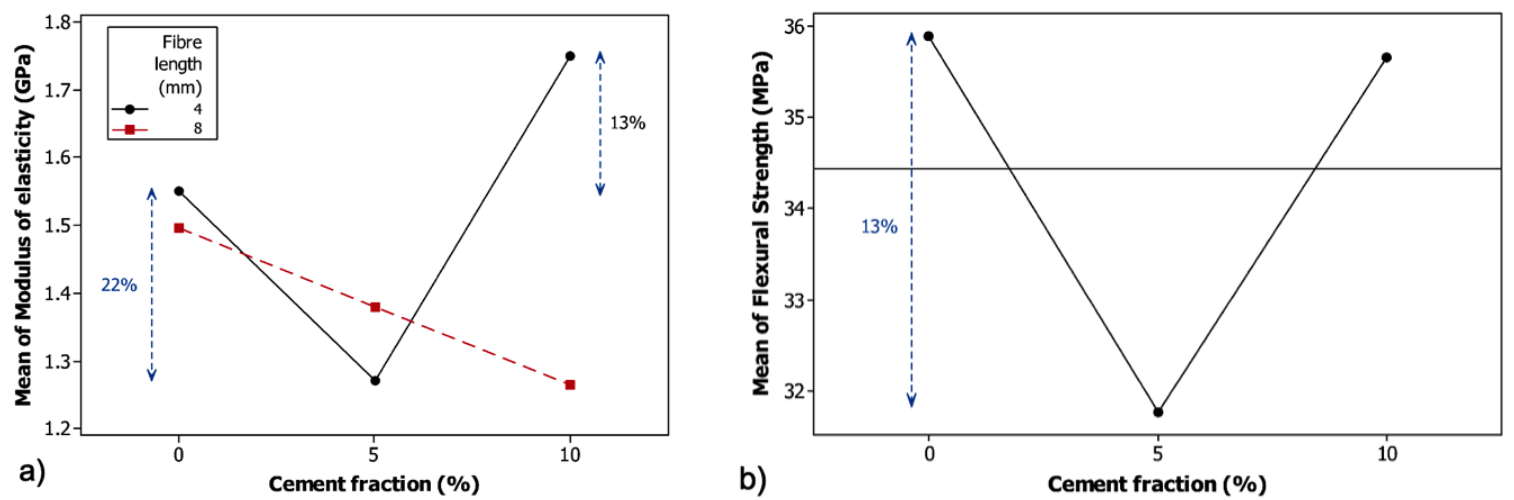

Figure 2: Interaction effect plot for the mean flexural modulus (a) and main effect plot for the mean flexural strength (b).

\subsection{Damping ratio}

The damping ratio of the composites varied from 0.0267 to 0.0337 (Table 2). The main factor "Cement inclusion" significantly affected the damping ratio response, with a P-value of 0.037 (Table 3 ). The main effect plot for the mean damping ratio (Figure 3) reveals the cement inclusion was able to increase the damping ratio of the composites, mainly when $5 \mathrm{wt} \%$ of particles were incorporated, exhibiting a percent increase of $25 \%$. It is noted the composites with lower stiffness/strength are those with higher damping ratio.

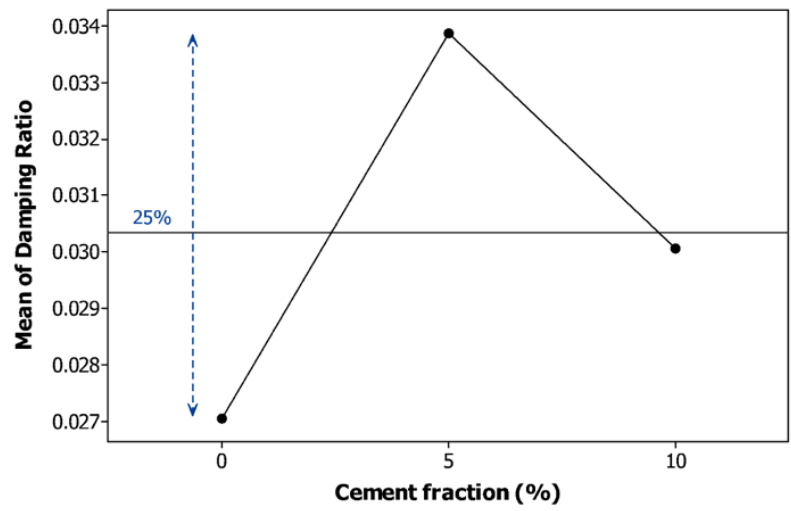

Figure 3: Main effect plot for the mean damping ratio.

\subsection{Apparent porosity and water absorption}

The apparent porosity of the composites ranged from $15.12 \%$ to $22.95 \%$ (Table 2). The P-value of 0.044 underlined in Table 3 indicates the main factor "Cement inclusion" significantly affected the apparent porosity results. Figure 4a shows the main effect plot for the mean apparent porosity data. The apparent porosity results raised when cement particles were incorporated. This behaviour can be attributed due to the increase of surface area while cement particles are incorporated. In addition, a wettability of the natural fibres is prone to reduce when cement particles are mixed with the epoxy resin, contributing to the presence of micro pores at the fibre/matrix interface.

The water absorption of the composites varied between $14.00 \%$ and $22.77 \%$ (see Table 2 ). The main factor "Cement inclusion" exhibited a significant effect on the water absorption, with a P-value of 0.046 (Table 3 ). Figure $4 \mathrm{~b}$ shows the main effect plot for the mean water absorption data. Similarly, as shown in Figure 4 a, a large increase in water absorption $(\approx 47 \%)$ was evident when cement particles were combined with the matrix phase. This behaviour can also be attributed to the low wettability of the sisal fibres and the particle surface area increasing, leading to the presence of micro pores around fibres and particles. 

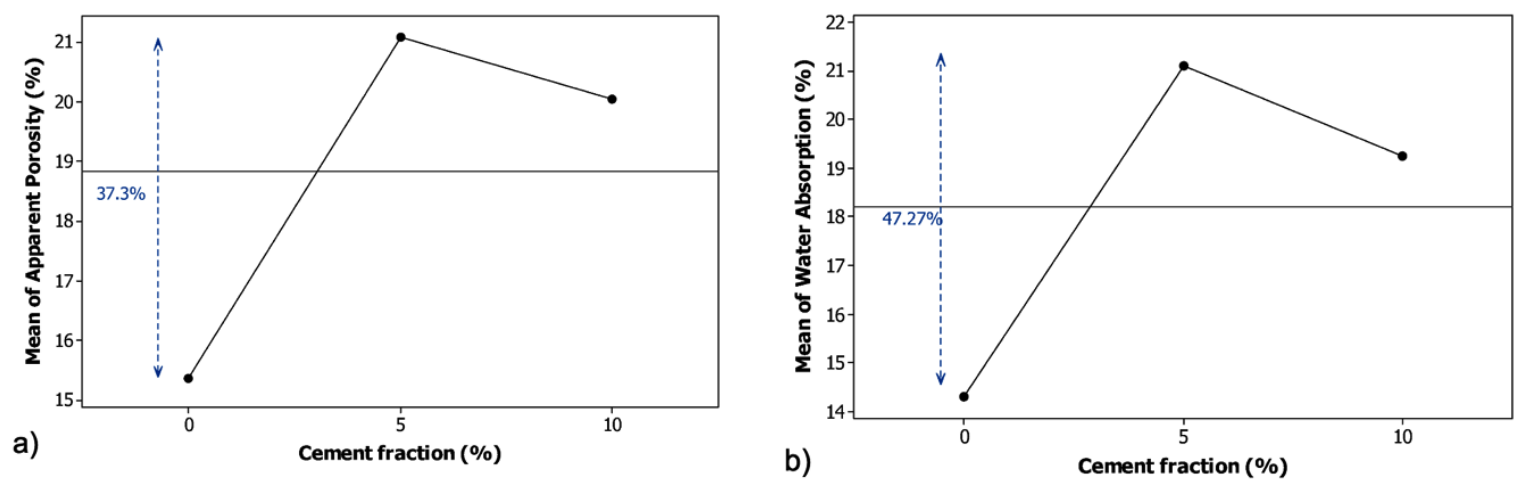

Figure 4: Main effect plots for the mean apparent porosity (a), and the mean water absorption (b).

\section{CONCLUSIONS}

This paper investigated the effect of Portland cement inclusions and sisal fibre lengths on the physical, dynamic and mechanical behaviour of short sisal fibre reinforced composites. A full factorial design was conducted to identify the effects of individual factors or interactions on the responses. The main factor Cement inclusion revealed significant effects on the flexural strength, damping ratio, apparent porosity and water absorption. Higher stiffness was achieved only when $10 \mathrm{wt} \%$ of cement particles were incorporated in composites made with sisal fibre length of $4 \mathrm{~mm}$. No significant effect was evidenced on strength when $10 \mathrm{wt} \%$ of cement was added, however a large reduction was reached when $5 \mathrm{wt} \%$ of cement was considered. The presence of cement particles increased the damping ratio, the apparent porosity and water absorption of the composites. The main factor Fibre length did not affect the responses. The interaction "Fibre length and Cement inclusion" exhibited significant effect only on the modulus of elasticity. The level of $10 \mathrm{wt} \%$ of cement particles did not contribute to the flexural strength of short fibre composites, however it can be considered a promising reinforcing phase, since it can enhance the durability of the matrix phase, especially when a possible cement hydration is considered. Finally, the presence of hydrated cement products and the particle location will be the scope of future investigations.

\section{ACKNOWLEDGMENTS}

The authors would like to thank CAPES, CNPq and FAPEMIG for the financial support provided.

\section{BIBLIOGRAPHY}

[1] SILVA, L.J., Estudo experimental e numérico das propriedades mecânicas de compósitos poliméricos laminados com fibras vegetais, Dissertação de M.Sc., Universidade Federal de São João Del-Rei, São João Del-Rei, MG, Brasil, 2011.

[2] ANGRIZANI, C.A., VIEIRA, C.A.B., ZATTERA, A.J., et al., "Influência do comprimento da fibra de sisal e do seu tratamento químico nas propriedades de compósitos com poliéster", $17^{\circ}$ CBECIMat - Congresso Brasileiro de Engenharia e Ciência dos Materiais, Foz do Iguaçu, PR, Brasil, Novembro 2006.

[3] MARTIN, A.R., MARTINS, M.A., MATTOSO, L.H.C., et al., "Caracterização química e estrutural de fibra de sisal da variedade agave sisalana", Polímeros: Ciência e Tecnologia, v. 19, n. 1, pp. 40-46, 2009.

[4] GIBSON, R.F. Principles of composite material mechanics, 2 ed, Ohio, McGraw-Hill, 1994.

[5] PAUL, A., JOSEPH, K., THOMAS, S. "Effect of surface treatments on the electrical properties of lowdensity polyethylene composites reinforced with short sisal fibers", Composites Science and Technology, v. 51, pp. 67-79, 1997.

[6] PAIVA, J.M.F., FROLLINI, E., "Unmodified and modified surface sisal fibers as reinforcement of phenolic and lignophenolic matrices composites: thermal analyses of fibers and composites", Materials Engineering, v. 291, pp. 405-417, April 2006.

[7] CAO, Y., CAMERON, J., "Impact properties of silica particle modified glass fiber reinforced epoxy composite", Journal of Reinforced Plastics and Composites, v. 25, n. 7, pp. 761-769, May 2006.

[8] SILVA, L.J., PANZERA, T.H., VELLOSO, V.R., et al., "Hybrid polymeric composites reinforced with sisal fibres and silica microparticles”, Composites: Part B, v. 43, pp. 3436-3444, January 2012. 
[9] SILVA, L.J., PANZERA, T.H., VELLOSO, V.R., et al., "Statistical design of polymeric composites reinforced with banana fibres and silica microparticles", Journal of Composite Materials, v. 47, n. 10, pp. 11991210, May 2012.

[10] MAHRHOLZ, T., STÄNGLE, J., SINAPIUS, M., "Quantitation of the reinforcement effect of silica nanoparticles in epoxy resins used in liquid composite moulding processes", Composites: Part A, v. 40, n. 3, pp. 235-243, March 2009.

[11] ROSSO, P., YE, L., FRIEDRICH, K., et al., "A toughened epoxy resin by silica nanoparticle reinforcement”, Journal of Applied Polymer Science, v. 100, n. 3, pp. 1849-1855, May 2006.

[12] TSAI, J.L., CHENG, Y.L., "Investigating silica nanoparticle effect on dynamic and quasi-static compressive strengths of glass fiber/epoxy nanocomposites”, Journal of Composite Materials, v. 43, n. 25, September 2009.

[13] ALAMRI, H., LOW, I. M., "Characterization of epoxy hybrid composites filled with cellulose fibers and nano-SiC”, Journal of Applied Polymer Science, v. 126, pp. 221-231, April 2012.

[14] ASTM D 790-07, "Standard Test Methods for Flexural Properties of Unreinforced and Reinforced Plastics and Electrical Insulating Materials", 2007.

[15] WERKEMA, M.C.C., AGUIAR, S., Planejamento e análise de experimentos: como identificar e avaliar as principais variáveis influentes em um processo, 1 ed, Werkema editora, Belo Horizonte, MG, 1996.

[16] COSSOLINO, L.C., PEREIRA, A.H.A., Amortecimento: classificação e métodos de determinação, Informativo Técnico-Científico, ITC04, São Carlos, 2010.

[17] SABA, N., JAWAID, M., ALOTHMAN, O.Y., et al., "A review on dynamic mechanical properties of natural fibre reinforced polymer composites”, Construction and Building Materials, v. 106, pp.149-159, March 2016.

[18] BRITISH STANDARD BS EN ISO 10545-3, Ceramic Tiles - Part 3: Determination of water absorption, apparent porosity, apparent relative density and bulk density. 1997.

[19] MONTGOMERY, D.C., Introduction to statistical quality control, 6 ed, New York, John Wiley \& Sons, 2009.

[20] DRUMOND, F.B., Metodologia de otimização de processos, Departamento de Estatística da UFMG, Departamento de Tecnologia Mineral do CDTN/CNEN, Belo Horizonte, Minas Gerais, 1993.

[21] PANZERA, T.H., SABARIZ, A.L.R., STRECKER, K., et al, "Propriedades mecânicas de materiais compósitos à base de cimento Portland e resina epóxi”, Cerâmica, v. 56, pp.77-82, Março 2010.

[22] DETOMI, A.C., SANTOS, R.M., RIBEIRO FILHO, S.L.M., et al., "Statistical effects of using ceramic particles in glass fibre reinforced composites", Materials and Design, v. 55, pp. 463-470, September 2013. 